\title{
Going archivally green: implications of doing it naturally in Southern African archives and libraries
}

\author{
Sandra Rowoldt \\ Cory Library for Historical Research, Rhodes University, P.O. Box 184, Grahamstown, 6140 Republic of South Africa \\ S.Rowoldt@ru.ac.za
}

\begin{abstract}
The conservation and preservation of archival and library materials is the concern of all those engaged in these professions. Considerable research has been conducted into ways in which archival and library materials may be conserved using structural rather than artificial means to control the environment. Piet Westra, former Director of the South African Library, initiated a wave of new thinking in this country when he invited Dr Helmut Bansa, Head of Conservation in the Bavarian State Library, Munich, to South Africa in November 1986. Dr Bansa's arguments in favour of the adoption of 'natural' methods of air-conditioning in libraries and archives (often referred to as the Cologne or Stehkämper model) stimulated the writer to explore the model further, particularly as it might be applied under local conditions. This article traces the development of research into the Cologne or Stehkämper model, its application in countries such as Germany, the Netherlands and Israel and promotes its adoption in the southern African context.
\end{abstract}

\begin{abstract}
Die bewaring en preservering van argiefmateriaal is belangrik vir almal betrokke by hierdie professies. Heelwat navorsing is gedoen ten opsigte van maniere waarop argief- en biblioteekmateriaal bewaar kan word deur strukturele eerder as kunsmatige maniere om die omgewing te beheer. Piet Westra, voormalige Direkteur van die Suid-Afikaanse Biblioteek, het 'n nuwe denkproses in Suid-Afrika geïnisieer toe hy dr Helmut Bansa, Hoof van Bewaring van die Bavariese Staatsbiblioteek, Munchen, in November 1986 hierheen genooi het. Dr Bansa se betoog ten gunste van die aanvaarding van 'natuurlike' metodes van lugreëling in biblioteke en argiewe (daar word dikwels daarna verwys as die Cologne of Stehkämper model) het die outeur gestimuleer om die model verder te ondersoek, veral hoe dit in plaaslike omstandighede toegepas kon word. In hierdie artikel word gekyk na die navorsingsontwikkeling oor die Cologne of Stehkämper model, die toepassing daarvan in lande soos Duitsland, die Nederlande en Israel en word die aanvaarding daarvan in SuidAfrikaanse konteks gepropageer.
\end{abstract}

Considerable research, mainly by German and Dutch archivists and engineers, has been conducted into ways in which archive and library materials may be conserved using structural rather than artificial means to control the environment. ${ }^{\prime}$ Piet Westra, former Director of the South African Library, initiated a wave of new thinking in this country regarding the conservation of records in Southern African libraries and archives when he invited Dr Helmut Bansa, Head of Conservation in the Bavarian State Library, Munich, to be the keynote speaker at the South African Library's 'Symposium on the Preservation of Library and Archival Materials in South Africa', 19-21 November 1986 (South African Library 1987).

Dr Bansa's arguments in favour of the adoption of 'natural' methods of air-conditioning in libraries and archives (often referred to as the Cologne or Stehkämper model) were compelling and have provoked further exploration in Southern Africa. In his keynote address to the Symposium, Bansa (1987b:17) stated:

'As a basic principle one should avoid air-conditioning whenever possible. It tends to break down, or to be switched off when energy is expensive. The climatic conditions that slow down the decay of paper and books should be provided primarily by architectural means'.

The responsibility for the conservation and preservation of a country's records rests firmly on the shoulders of all archivists. It is also the responsibility of archivists to look at the broader issues of diminishing energy resources as well as the ever-rising costs of energy in serving their archives' environmental needs. In the first instance it is incumbent upon them to try, to the best of their ability, to prevent damage to the documents in their care. Hugo Stehkämper, Director of the Historical Archives of the City of Cologne, has written

'Every restorer knows that prevention, rather than restoration of damage is the best method of preserving cultural assets and, most important, it is also the cheapest. ... Of all sources of damage - bombs, water, fire, sun, vermin, dirt, theft, thoughtless users - extreme temperatures and humidity, i.e. poor or incorrect air conditioning, play a particular role in the case of parchment and paper ... Damage caused by poor climate often sets in unnoticed, its progress generally escaping the naked eye; to my knowledge there are no measuring instruments for detecting it as it arises. With little likelihood of being able to combat and eliminate the danger in good time, the consequences of poor or incorrect air conditioning generally affect the entire stock of parchment or paper, whereas the havoc wrought by sun or fire is often confined to the edges of a stack of paper and the topmost sheets. A decline in climate takes its toll insidiously but thoroughly' (Stehkämper 1988:163).

What should be aimed at is the maintenance of a 'thermodynamic equilibrium by optimally preparing or conditioning the air' in which documents are stored and in which they are 
consulted (Stehkämper 1988:164). In considering how the air is prepared or conditioned archivists should remember that

'the whole object of proper air conditioning is to control the exchange of air and heat between the stored library and archival material and the outside world, supplying the most amenable temperature and relative humidity and pure air' (Stehkämper 1988: 163).

Although archivists are familiar with the parameters for the successful and long-term storage of paper-based documents in terms of temperature and relative humidity there is no incontestable international standard that holds ultimate sway. As Stehkämper points out, paper technicians, archivists and librarians generally propound what he calls 'experimental values'. For example, European temperature parameters range from $15^{\circ} \mathrm{C}-18^{\circ} \mathrm{C}$ and those for relative humidity from $50 \%$ to $65 \%$ (Stehkämper 1988:164). In the United Kingdom the British Standard recommendations (British Standard 5454) for temperature are $13^{\circ} \mathrm{C}-18^{\circ} \mathrm{C}$ and $55 \%-65 \%$ for relative humidity (Duchein 1988: 105). As paper is a slow conductor of heat and humidity, these are all safe tolerance zones. However, the less the variance in temperature and relative humidity, and the longer the time period over which this variance is manifested, the less the danger of fibre stress within the documents.

\section{Historical Archives of the City of Cologne, Germany}

Stehkämper began in Cologne by examining the ways in which thermodynamic equilibrium can best be maintained and in this process he looked to the experience of the past. Cologne's paper records had been kept in what Wolf Buchmann describes as 'a large rock-walled tower' from the beginning of the fifteenth century to the end of the nineteenth century (Buchmann 1993:3).

In the interests of preservation, and in the light of what was then considered superior technology, these documents were moved from their medieval storage areas into a newly constructed building which was considered more appropriate. By the middle of this century, it was evident that the records had deteriorated more in this building during six decades than during more than four centuries in the old, thick-walled, medieval buildings (Buchmann 1993:2-3).

Planning for a third building was begun and it seemed obvious that whilst it would not be practical to construct twentieth century archive buildings along the same massive lines, with walls several metres thick, what the planners and engineers needed to attempt was to emulate the effect of these medieval buildings, using modern concepts and materials in the construction process. In the designing of the new Cologne Archives building, 'natural' air-conditioning in the stack areas was realised by means of a triple-layer wall design, good building materials and well-planned window placement (Buchmann 1993:3).

In Cologne, the triple-layer wall consists of a doublethickness brick wall measuring $49 \mathrm{~cm}$ in depth, followed by a $7 \mathrm{~cm}$ airspace and screened by a granite slab facade. Bricks are known to be poor conductors of heat and are therefore slow to react to external temperature and relative humidity fluctuations. The effect of the airspace between the bricks and the facade creates a current of air which, as Stehkämper explains, 'reinforces the insulating effect and affords thermal relief to the brick wall'. The facade itself acts as a shield against the often extreme changes of climate (Stehkämper 1988:168).

The judicious arrangement, size and number of windows further reinforces the implementation of 'natural' air-conditioning by ensuring that the mass of the wall is not overly reduced by a surfeit of oversized apertures. In Cologne the windows are glazed with milk glass, they open vertically, are small and are few in number (Rowoldt 1993:3).

Various permutations of this basic Cologne or Stehkämper model have been implemented in archival repositories in Europe and beyond, but principally in Germany, the Netherlands and Switzerland.

\section{Maastricht and Limburg Regional Archives, Maast- richt, Netherlands}

In Maastricht, in the Netherlands, the City and Limburg Regional Archives have recently been extended. When the archives were established in 1880, they were housed in a thirteenth century church, with great stone walls and massive pillars. In 1940, they spread over into the cloister area and in 1988 the present extension on the same site was begun. As the area was an historical area, and very confined, it was decided to build three stack areas underground in the courtyard between the church and the cloisters. In this way the archivists - and the architects - believed that both objectives would be achieved: that of preserving the integrity of the historic area, and of constructing premises that would house archival records with minimal costs for environmental control. They expect to achieve levels of $16^{\circ} \mathrm{C}-18^{\circ} \mathrm{C}$ temperature and a relative humidity level of $55 \%$. As an extra energysaving measure, lighting is sound activated in the stack areas and will come on automatically for only 10 minutes at a time. In the staff work areas, up-lighting is used to achieve maximum illumination without stressful and expensive over lighting and resultant glare. The subterranean archives were completed in 1995 and Southern African archivists can learn much from their planning and experience (Rowoldt 1993:34).

However, all the examples cited above describe applications of the Cologne or Stehkämper model in northern European climatic conditions. It may be interesting to examine three examples of archives and museums constructed in conditions closer to those in Southern Africa, all in Jerusalem (Rowoldt 1997:35-43).

\section{Central Zionist Archives, Jerusalem, Israel}

The Central Zionist Archives was founded in 1919 under the auspices of the World Zionist Organisation. It houses 8180 linear metres of files, 1000 private archives and collections, 
545000 pictures, 490 magnetic tapes, 125000 volumes, 8430 newspapers and 240000 items of small printed matter. The Archives houses records of the World Zionist Organization, the Jewish Agency for Palestine/Israel abroad, associated territorial Zionist groupings, the World Jewish Congress and institutions established by them, as well as documents on the history of Zionism in various countries throughout the world, including South Africa (Central Zionist Archives 1993:v-vi).

The present building was designed by Moshe Zarhi and is the first structure in Israel planned and built especially as an historical archives (Central Zionist Archives 1993:vii). Building commenced in 1985 and was completed two years later. At this time utilities such as electricity were under the control of the Israeli government and electrical costs were spiralling. The archivists and designers were concerned that they should be able to achieve appropriate environmental conditions for their collections without total dependence on full velocity airconditioning and to do this they turned to the Cologne or Stehkämper model for guidelines. The idea from the outset was, however, to reduce air-conditioning costs, not to do away with air-conditioning altogether. The Director, $\mathrm{Mr}$ Yoram Mayorek, believes that it would not be possible to maintain stable temperature and relative humidity without some artificial environmental controls given Jerusalem's climate. In a personal interview with the author, he also warned against the wholesale and unadapted transplantation to Southern Africa of ideas developed in other climes. However, this response may have been as a result of the limited success of the Cologne or Stehkämper principles as modified in the Central Zionist Archives.

The Central Zionist Archives is built on sloping land and has two ground floor entrance levels. The archive is a flatroofed, six-storey building with two floors above ground (which house the public and staff work areas) and four subterranean floors (which house the archival strongrooms). Construction is of local brick with supporting columns of concrete and clad in Jerusalem stone. Windows are half-moon in shape and their proportion of the overall external area is minimal.

The construction of the underground floors follows the Cologne or Stehkämper model in principle, with some modifications. The strongrooms are surrounded by a $1.5 \mathrm{~m}$ air schacht or shaft between the outer wall of the building and an external exterior wall. This schacht surrounds all four of the subterranean floors. It also houses emergency exits from the strongrooms and staircases in case of fire.

There was some debate prior to construction as to whether the schacht should be left open or closed at surface level. Eventually the decision was taken to close the schacht at the top and on each floor with the exception of a small smoke exit running around the building and a fire escape staircase in one corner.

The result has been that the schacht acts as a humidity trap. The external exterior reinforced concrete walls are not water resistant and no water-proofing material was used to line the outside or the inside of the schacht walls. The result is that during winter or damp conditions, water trickles down the inside of the exterior wall - in fact it drips audibly and visibly inside the schacht at the height of Jerusalem's dry season. Even the sprinklers used during the hot, dry summer months on the surrounding lawns and gardens cause water to seep through and run down the walls of the schacht. There is a small channel running around the perimeter of the schacht to catch the water and large electrical water pumps stand by to pump out the excess once it reaches a determined level. Using a more defined slope in the drainage channels and other simple drainage measures would have taken the water outside and beyond the perimeters of the building without the necessity for expensive electrically-operated pumps.

Had the schacht had grilles at the top instead of being sealed, these would have let in the rain but the amount of rainwater entering the schacht would have been minimal and the open grilles would have allowed for faster evaporation. The insulating effect of the schacht would, however, have been reduced by having the grilles open.

At present, the Central Zionist Archives cannot control the effect of the water seepage. The humidity which builds up in the schacht finds its easiest route - through the strongroom walls and into the archival storage areas. Conditions within the strongrooms are adversely affected and the air-conditioning, which was originally installed to do the minimum necessary to maintain optimum conditions, has to counteract the considerable humidity seeping through from the schacht.

Some believe that as the external exterior walls are freestanding, the pressure building up in the earth mass would have caused them to collapse had they been made watertight. This conjecture will have to be confirmed or disproved but other Cologne or Stehkämper model archives with subterranean strongrooms have simply and successfully used strong plastic waterproofing to good effect, for example, at Maastricht.

The strongrooms each cover an area of $900 \mathrm{~m}^{2}$. Two of them have mechanically operated compactus shelving (using wheel-winders on the stack ends) and all floors have been reinforced in preparation for its installation when the need arises. Mechanically operated compactus has been installed rather than the electrically powered option for both energysaving and operating reasons and it is easily operated.

Fire protection is achieved through a wax-controlled water system. Pipes with sprinklers run at ninety degrees to and $0.5 \mathrm{~m}$ above the shelving. Each sprinkler is blocked with wax with a melting point of $45^{\circ} \mathrm{C}$. Only the wax in a sprinkler directly affected by the heat of a fire will melt, limiting the discharge of water to the area immediately above the fire assuming, of course, that the fire is small and contained. Internationally, authorities remain divided on the issue of the use of water for fire control but many archives are reverting to water in preference to halon or other gases because of its harmless effect on humans. Indeed, in many countries, the use of gases for fire control is prohibited. However, gas has been installed in most of the German archives examined above. 
This is a vexed debate: on the one hand, water can cause as much damage to archival materials as any fire; on the other hand, injudicious use of gas can kill. These factors emphasise the importance of fire precautions and prevention - and a good measure of hope that neither system of fire control will ever have to be called into action.

In Israel there is a further issue to be considered in ensuring the preservation of archives. In view of the volatile political situation in Israel, people in general are alert to the danger of hostile activity and this means that the archives must have an independent water source as, in the event of hostilities in the city, public services and supplies would doubtless collapse. This would, of course, also apply to the power needed to maintain their air-conditioning plants.

In the Central Zionist Archives, where a modified version of the Cologne or Stehkämper model has been implemented, they could have doubtless achieved what they set out to do had they water-proofed the external exterior wall of the basement.

In Germany, Cologne or Stehkämper principles are also reported to have been modified with less than successful results in the building of the Bundesarchiv, Koblenz, evidently with disastrous results. Water apparently runs down the inside of the archive walls in Koblenz as it does inside the walls of the schacht of the Central Zionist Archives in Jerusalem.

\section{Israel Museum, Jerusalem, Israel}

The Israel Museum was built in 1965 and was equipped with high-velocity air-conditioning throughout, sourced by several independent plants. However, their Director of Conservation, $\mathrm{Mr}$ Michael Maggen, who is fully conversant with the Cologne or Stehkämper principles, has experienced the deterioration of a sophisticated and expensive air-conditioning system. Over time, a number of the plants have been upgraded and replaced, including those supplying the Conservation Division. However, the original ducting was not replaced at the same time and serious deterioration of the cladding within the ducting has taken place. The result of this has been the high-velocity discharge of fine fragments resembling soot into the Conservation areas which not only impedes the quality of their precision restoration work of priceless art and textual works, often of great antiquity, but is having adverse effects on the health of his Conservation staff who inhale the affected air throughout their working day. Though items are given protective covering between work sessions to minimise damage, pollution from the ducting may be seen lying on the work surfaces in the Conservation area.

To minimise the volume of particles pouring into the work area, mesh filters have been constructed by the Conservation staff and placed across the vents. Whilst this proved effective for a short period, banks of particles built up behind the mesh. These eventually burst through, distributing large concentrations of particles at high velocity throughout the area. The Conservation specialists are fighting a daily, uphill battle against an inappropriate and inadequate system of environmental control.

In the Conservation Division storeroom, water leaks from the roof level. This is proving to be a severe problem and some of their valuable collections may be at some risk. Cladding over the air-conditioning ducting is being affected and there is visible damp on the ceiling and walls. Plans had been made to rectify these problems.

\section{Steven Spielberg Jewish Film Archive, Hebrew University, Jerusalem, Israel}

The Steven Spielberg Jewish Film Archive has been housed in immaculate, state-of-the-art conditions in the Hebrew University since 1996. They have full air-conditioning for their film and video archives which is functioning adequately if a little erratically. Hitherto, their archives were housed for 22 years in the thick-walled basement of another building in the University. During these 22 years, the archives suffered no deleterious effects, despite the total lack of air-conditioning. Temperatures were stable and there were no relative humidity problems. Given that film and video requires more stringent climatic standards than do paper-based archives, the success of this natural conservation is remarkable.

The Steven Spielberg Jerusalem Film Archive is administered jointly by the Avraham Harman Institute of Contemporary Jewry of the Hebrew University of Jerusalem and the Central Zionist Archives. The Archive holds more than 10000 cans of film and 5000 video cassettes documenting Jewish history and culture and is the largest collection of Jewish/Israeli documentary films (Steven Spielberg Jewish Film Archive 1997:1-2).

The Spielberg Archive moved into luxurious new facilities on the Mount Scopus campus of the Hebrew University of Jerusalem in October 1996. The archive is located in the Humanities Building and may be of particular interest as this is the only one of the institutions described which occupies a multi-purpose, university building. (Steven Spielberg Jewish Film Archive newsletter 1997:[1]).

The area which the archive presently occupies was originally designed as a kitchen and has been imaginatively adapted by the architect. Special emphasis was placed on the archival aspects of cataloguing, accessibility and customer service. The area includes separate film and video vaults (both with a double-door lobby to allow for gradual adjustment of the material from the cooler temperature of the vault to the temperature in the viewing rooms and theatre). International standards require that black and white film and video should be stored at $12^{\circ} \mathrm{C}$ with a relative humidity of $20 \%$ to $35 \%$. Environmental variation should not be more than $1{ }^{\circ} \mathrm{C}$ and $5 \%$ RH. Colour film requires an even lower temperature: $\pm 5^{\circ} \mathrm{C}$. The Spielberg Film Archives are experiencing difficulties in achieving these ideals in their new premises, despite state-of-the-art environmental equipment. Engineers are called in repeatedly to help them adjust the temperature and RH levels. Their thermohygrographs do not record these 
readings automatically. Figures are charted manually by the staff on forms attached to the walls.

A survey of the professional literature indicates that there is also evidence that full air-conditioning can produce adverse conditions for the preservation of documents as well as for the well-being of archives personnel and users.

The question remains: is there anything that archivists and librarians in Southern Africa can derive from the Cologne or Stehkämper model?

\section{Stellenbosch University, South Africa}

In South Africa, Stellenbosch University has designed one of the largest underground libraries in the world and it is undeniably very successful. Heather Edwards, University Librarian of the University of the Witwatersrand, writes

'The architects, concerned with the surroundings as well as with the building, have managed to design a modern and highly functional library in a historic environment without its dominating or detracting from the latter' (Edwards 1990:83).

Edwards (1990:76) continues

'The walls of the library consist of three layers: an outer layer of durable damp-proof material, an outer wall of $200 \mathrm{~mm}$ ( 8 ins)-thick of waterproof reinforced concrete separated by a space from the inner wall. This enables any water entering the area to be drained off'.

Careful attention has been given to drainage and insulation, particularly with regard to the foundations. There is effective underground and roof drainage linked to a pump house to ensure that all water drained from the outer surfaces of the building is led away via gravitational piping. This helps obviate the problem of condensation, which can occur when the surrounding earth is cooler than the internal temperature of the building and also helps reduce the need for artificial environmental controls.

As Edwards (1990:76) explains,

'The influence of daily and seasonal temperature changes is reduced to a large degree because the large mass of earth surrounding the structure modifies the effect of rapid fluctuations in outdoor temperature. The building reacts very slowly to any change, and sudden changes have no effect whatsoever. The costs of cooling are thus low, and are estimated at a third to half the costs of a similar building above ground. The building is thus efficient in terms of energy consumption, and running costs are low. The air conditioning system dissipates the heat build-up caused by the presence of people and lighting in the large internal areas, making use of cool outside air whenever possible' .

There is good reason to believe that the principles of subterranean construction can be applied in Southern Africa to good effect. Appropriate insulating materials will have to be used to preclude underground water seepage and methods of ensuring quality of air supply will have to be investigated.

\section{A Southern African renaissance}

The wholesale transplantation of the European model to other climes, including Southern Africa, would not be sufficient to effect the achievement of an appropriate archival environment without taking into account our particular local conditions. Southern African archives planners and architects should take into account all site-specific factors: for example, the slope of the site; solar orientation; wind vectors; the use of natural, local materials such as clay, stone and wood; the use of overhanging eaves; and the retention of existing trees to shade the building. In other words, they should attempt to effect locally-adaptive, natural means to insulate the building (Edwards 1993:6-12).

Wherever the Cologne or Stehkämper model is implemented, Stehkämper stresses the practical and economic necessity of using local, natural materials wherever possible. Where marble or granite may not be available, local options such as clay, quarry tiles or sandstone could be used. It is economically and practically counter-productive to import products where locally produced materials can serve the same thermodynamic purposes. In Maastricht, the lovely yellow local stone (Mergel kalk), which was used in the construction of the old church and which is quarried close by, was used in the construction of the new building. This choice made aesthetic, practical and economic sense.

Similarly, and very importantly, cognisance should be taken of local climate-adaptive building patterns and, where feasible, to draw on the domestic building experience. It is obvious that buildings should be orientated appropriately on the site to minimise daytime heat transference. However, South African archivists and archive designers should also look at adapting other local practices, like the use of overhanging eaves so often seen in the construction of domestic buildings in warm climates, to shelter archive walls from hot sunlight. Think of South African domestic architecture and how it adapts to our climate. Then look at most institutional buildings and how that adaptation is generally ignored.

Whilst some degree of artificial air-conditioning will probably have to be implemented in order to attain optimal environmental conditions for the preservation of archival records and to ensure air quality, one thing is certain. We, in Africa, face a wide range of climatic fluctuations. We also face diminishing energy resources, the prospect of ever increasing energy costs and, certainly in the Eastern Cape, the unpredictable continuity of energy supply. Any mode of construction which optimises design principles towards the achievement of an appropriate environment for Southern African archival collections with minimal wastage of energy and money must be explored. The Stehkämper or Cologne model, in any of its permutations, may require that more is invested at the construction stage in terms of thicker walls, insulation and the use of good, local building materials. However, when this increased investment is weighed against the high costs of installation and the even higher costs of 
maintenance and running costs of intensive artificial environmental controls, there would seem to be much to be gained by considering this option.

The subterranean method, as used at Cologne, Maastricht and the Central Zionist Archives for example, is undoubtedly worth pursuing in South Africa. As Verne Harris (1993:1617) points out

'The subterranean model ... seems to hold the most promise in South Africa. As the Union Buildings and Transvaal Museum basements have shown, on the highveld this option can completely preclude the need for artificial climate control. And the Stellenbosch University Library has established that in the Western Cape a subterranean design can substantially reduce reliance on artificial means'.

Several renowned archives, libraries and galleries around the world have, in recent years, installed high-velocity airconditioning for the environmental protection of some of mankind's greatest cultural and historical treasures. Unaffordable running costs (in one known case in excess of R30 000 per month to run the air-conditioning plant alone) as well as factors such as erratic power supply and system malfunctioning have resulted in the highly sophisticated airconditioning systems in these institutions being switched off, to the obvious detriment of the treasures therein.

Factors such as urban and industrial pollution must be taken into account though these factors may not pose too much of a threat in some of the smaller, less-industrialised South African centres where archives buildings are sited, such as in the Eastern Cape. Further, the threat of water intrusion (as in the case of Maastricht or the new Bibliothèque de France on the banks of the Seine in Paris) may not affect many parts of South Africa which are not blessed with a bountiful and consistent rainfall, which are not adjacent to water sources in the form of oceans, lakes or rivers and whose water tables are distressingly low in terms of productivity and development. However, while these conditions may not serve our economy or our environmental needs, there are spinoffs for the construction of archival buildings. Nonetheless, there is no room for complacency and precautions against the possibilities of pollution and water intrusion must be considered.

To choose a South African example, Grahamstown figures reflect a more moderate and distributed annual rainfall than that of Jerusalem. Whilst the Grahamstown climate shares similar extremes with that of Jerusalem (for example), there are some happy dissimilarities. Jerusalem experiences consistently higher temperatures over a period of up to seven months at a time from April through October. These protracted and unrelieved hot periods give their buildings time to absorb external temperatures and lead to a build-up of inner building temperatures. Whereas Grahamstown generally experiences a few days of extremely high temperatures during the summer months, especially January to March, these are invariably tempered by intervening days of milder - even chilly - weather, which prevents the relentless build-up of heat inside local buildings. Similarly, Grahamstown winter temperatures fluctuate sufficiently to prevent severe loss of inner building temperature. Whilst Grahamstown may experience temporary high and low extremes, its temperature data presents a gentler annual curve than that of Jerusalem and this must be to Grahamstown's advantage.

\section{Conclusion}

There can be no doubt that the Cologne or Stehkämper principles are effective and there can be no doubt that Southern African archivists and archival architects should consider how they may be implemented in the Southern African environment. Initial building costs will be slightly higher. These higher initial costs will, however, obviate two ongoing and high expenditures: in the first instance, the cost of installing and maintaining high-velocity air-conditioning and, in the second instance, the cost of remedial conservation and restoration measures which would be required if archival materials were stored in an unsuitable environment.

Piet Westra's initiative in bringing Helmut Bansa to South Africa must give us all pause when planning our new archival buildings. After all, Dr Bansa himself pointed out the unintended but effective conservation environment which had been achieved by storing State archives in the thick-walled basement of the Union Buildings (Bansa 1987a:24).

We should heed Dr Bansa's warnings and advice, and consider adopting the Cologne or Stehkämper model for archives in the Southern African environment as a matter of principle. In simple economic terms alone we can do no other.

\section{Note}

1. In preparation for the planning of the new Cory Library in Grahamstown, the author visited several archives and library buildings in Europe, the United Kingdom and Israel in April/May 1993, July 1995 and June 1997 respectively. Archives and libraries visited in 1993 included the archives of the Rijksuniversiteit Utrecht Library, the Gemeente Archief in Utrecht, the Algemeene Rijksarchief in The Hague and the Rijksarchief Limburg in Maastricht (all in the Netherlands); the Historisches Archiv der Stadt Köln in Cologne, the Bayerische Staatsbiblioteek in Munich and the Westfälisches Wirtschaftsarchiv in Dortmund (all in Germany); and the Bibliothèque de France in Paris. The author also attended a two-week British Council course on Library planning and design at the Robinson Library of the University of Newcastle-upon-Tyne, 19-30 April 1993. During this course, candidates visited the Central Library, Newcastleupon-Tyne, the new National Library of Scotland in Edinburgh and the Joule Library, University of Manchester Institute of Science and Technology (UMIST). In July 1995, the author returned to the completed Rijksarchief Limburg (Maastricht) and in June 1997, visited the Central Zionist Archives, the Israel Museum and the Steven Spielberg Jewish Film Archive, all in Jerusalem. The visits to Israel were conducted to gain on-site 
experience of environmental controls in archives and museums in a climate more resembling South African conditions. Much of the information presented in this article was gleaned from personal observation and interviews with the curators of the repositories visited, supported by relevant readings.

\section{References}

Bansa, H. 1987a. Book and paper conservation in South Africa, unpublished report on a visit October/November 1986 prepared for the Department of National Education, Pretoria. Munich: 1987.

Bansa, H. 1987b. Preservation of library materials: an international challenge. In Books in peril. Cape Town: South A frican Library.

Buchmann, W. 1993. The control of environment conditions in a new archives building (Bundesarchiv in Koblenz). Unpublished paper.

Central Zionist Archives. 1993. The future of our past: the Central Zionist Archives and its collections. Jerusalem: The Archives.

Duchein, M. 1988. Archive buildings and equipment. 2 rev and enl. ed. Munich: K.G. Saur.
Edwards, H. 1990. University library building planning. Methuen, N.J.: Scarecrow Press.

Edwards, H. 1993. Building design for energy economy, AMLIB newsletter, (53)November:6-12.

Harris, V. 1993. Going for green : public archives buildings in South Africa and the prospects for natural climatic control, AMLIB newsletter, (53)November:12-18.

Rowoldt, S. 1993. The greening of archive buildings: natural airconditioning in the Southern African context. Janus: archival review, (2):36-41.

Rowoldt, S. 1997. Jerusalem: visits to archives and museums, June 1997. South African archives journal, (39):35-43.

Stehkämper, H. 1988. Natural air-conditioning of stacks. Restaurator, 9:163-177.

South African Library. 1987. Books in peril. Prodeedings of the Symposium on the Preservation of Library and Archival materials in South Africa, held at the South African Library, Cape Town, 19-21 November 1986. Cape Town: South African Library.

Steven Spielberg Jewish Film Archive newsletter. 1996-7. Jerusalem: The Archive.

Steven Spielberg Jewish Film Archive. 1997. [Online]. Available: http://www2.huji.ac.il/www_jcj/jfabroch.html 